\title{
New host, geographic records, and histopathologic studies of Angiostrongylus spp (Nematoda: Angiostrongylidae) in rodents from Argentina with updated summary of records from rodent hosts and host specificity assessment
}

\author{
María del Rosario Robles ${ }^{1}{ }^{+}$, John M Kinsella² ${ }^{2}$ Carlos Galliari', Graciela T Navone ${ }^{1}$ \\ ${ }^{1}$ Centro Científico Tecnológico-Consejo Nacional de Investigaciones Científicas y Técnicas, \\ Centro de Estudios Parasitológicos y de Vectores, Buenos Aires, Argentina ${ }^{2}$ HelmWest Laboratory, Missoula, MT, USA
}

To date, 21 species of the genus Angiostrongylus (Nematoda: Angiostrongylidae) have been reported around the world, 15 of which are parasites of rodents. In this study, new host, geographic records, and histopathologic studies of Angiostrongylus spp in sigmodontine rodents from Argentina, with an updated summary of records from rodent hosts and host specificity assessment, are provided. Records of Angiostrongylus costaricensis from Akodon montensis and Angiostrongylus morerai from six new hosts and geographical localities in Argentina are reported. The gross and histopathologic changes in the lungs of the host species due to angiostrongylosis are described. Published records of the genus Angiostrongylus from rodents and patterns of host specificity are presented. Individual Angiostrongylus species parasitise between one-19 different host species. The most frequent values of the specificity index $\left(S_{T D}\right)$ were between 1-5.97. The elevated number of host species $(n=7)$ of A. morerai with a $S_{T D}=1.86$ is a reflection of multiple systematic studies of parasites from sigmodontine rodents in the area of Cuenca del Plata, Argentina, showing that an increase in sampling effort can result in new findings. The combination of low host specificity and a wide geographic distribution of Angiostrongylus spp indicates a troubling epidemiological scenario although, as yet, no human cases have been reported.

Key words: Angiostrongylus - histopathology - host specificity - rodents - Sigmodontinae - Argentina

The main definitive hosts of angiostrongylid nematodes of the superfamily Metastrongylidoidea are carnivores and rodents and the known intermediate hosts are molluscs (e.g., Acha \& Szyfres 2003). To date, 21 species of the genus Angiostrongylus Kamensky 1905 have been reported around the world. Six species have been described infecting carnivores: Angiostrongylus vasorum Baillet 1866, Angiostrongylus raillieti Travassos 1927, Angiostrongylus gubernaculatus Dougherty 1946, Angiostrongylus chabaudi Biocca 1957, Angiostrongylus daskalovi Yanchev \& Genov 1988, and Angiostrongylus felineus Vieira et al. 2013, and the remainder from rodents: Angiostrongylus tateronae Baylis 1928, Angiostrongylus cantonensis (Chen 1935), Angiostrongylus sciuri Merdevenci 1964, Angiostrongylus mackerrasae Bhaibulaya 1968, Angiostrongylus sandarsae Alicata 1968, Angiostrongylus petrovi Tarzhimanova \& Chertkova 1969, Angiostrongylus dujardini Drozdz \& Doby 1970, Angiostrongylus schmidti Kinsella 1971, Angiostrongylus costaricensis Morera \& Céspedes 1971, Angiostrongylus malaysiensis Bhaibulay \& Cross 1971,

doi: 10.1590/0074-02760150371

Financial support: ANPCyT (PICT 0924, 1634, 0547)

MRR, CG, and GTN are members of CONICET.

+ Corresponding author: rosario@cepave.edu.ar

Received 29 September 2015

Accepted 1 February 2016
Angiostrongylus ryjikovi (Jushkov 1971), Angiostrongylus andersoni (Petter 1972), Angiostrongylus siamensis Ohbayashi, Kamiya \& Bhaibulaya 1979, Angiostrongylus morerai Robles, Navone \& Kinsella, 2008, and Angiostrongylus lenzii Souza et al. 2009 (Baillet 1866, Travassos 1927, Baylis 1928, Dougherty 1946, Mackerras \& Sandars 1955, Biocca 1957, Merdivenci 1964, Alicata 1968, Bhaibulaya 1968, Tarzhimanova \& Chertkova 1969, Bhaibulaya \& Cross 1971, Doby et al. 1971, Jushkov 1971, Kinsella 1971, Morera \& Céspedes 1971, Petter 1972, Ohbayashi et al. 1979, Yanchev \& Genov 1988, Robles et al. 2008, Souza et al. 2009, Vieira et al. 2013, Spratt 2015). Except for two species, A. costaricensis and $A$. siamensis, which infect the mesenteric arteries of the caecum, all species inhabit the pulmonary arteries and right ventricle of the heart.

Among rodents, species of Angiostrongylus are distributed in the Cricetidae, Echimyidae, Gliridae, Heteromyidae, Muridae, and Sciuridae. The best studied and most widely distributed species are $A$. cantonensis and $A$. costaricensis, which are primarily parasites of rodents but carnivores, marsupials and primates have also been recorded as definitive hosts (Maldonado et al. 2012) as well as abnormal/aberrant hosts (Spratt 2015). Both species are recognised as zoonotic; the first is the cause of the disease eosinophilic meningoencephalitis from different continents and the second of abdominal angiostrongyliasis from the Americas (Acha \& Szyfres 2003, Maldonado et al. 2012, Spratt 2015).

The life cycles of eight species parasitising rodents have been studied: A. andersoni, A. cantonensis, $A$. costaricensis, A. dujardini, A. mackerrasae, A. malay- 
siensis, A. siamensis, and A. schmidti. In those species inhabiting the pulmonary arteries, eggs deposited by adults develop to first stage larvae in the lungs which move up the airways, are swallowed and pass in the faeces. This developmental pathway is exemplified by $A$. andersoni, $A$. dujardini, and A. schmidti (Kinsella 1971, Bhaibulaya 1975, Mota \& Lenzi 2005, Spratt 2015). The resultant pathology has been described in species such as $A$. cantonensis, $A$. costaricensis, A. mackerrasae, A. morerai, A. sandarsae, A. schmidti, and A. siamensis (Mackerras \& Sandars 1955, Alicata 1968, Kinsella 1971, Tesh et al. 1973, Ohbayashi et al. 1979, Mota \& Lenzi 2005, Robles et al. 2012).

One of the most important properties characterising a parasite taxon is its host specificity. It is indicative of intrinsic biological characteristics of both host and parasite and an emergent property of their ecological and evolutionary relationship (Dick \& Patterson 2007). Host specificity can be defined as the extent to which a parasite taxon is restricted in the number of host species used at a given stage in the life cycle (Poulin 2007).

In this paper, we provide new host and geographical records for two species of Angiostrongylus from sigmodontine rodents in Argentina and describe the gross and histopathologic changes in the lungs of the host species due to angiostrongylosis. Moreover, we present comprehensive data on all the records of the genus Angiostrongylus from rodents and evaluate patterns of host specificity.

\section{MATERIALS AND METHODS}

Cricetid rodents were trapped during different field studies between 2007-2012 (see acknowledgements and financial support) and the following species were examined for angiostrongylid nematodes: eight specimens of Deltamys kempi Thomas 1917 from Reserva Natural de la Costanera Sur (34 $36^{\circ}$ S $\left.58^{\circ} 27^{\prime} \mathrm{W}\right)$, Ciudad Autónoma de Buenos Aires and La Balandra (34 $56^{\circ}$ 'S 57 $7^{\circ} 2^{\prime} \mathrm{W}$ ), Partido de Berisso, province of Buenos Aires, 11 specimens of Akodon montensis Thomas 1913 from RP2, $6 \mathrm{~km} \mathrm{NE}$, Arroyo Paraíso, (27 $\left.12^{\prime} 47.7^{\prime \prime} \mathrm{S} 54^{\circ} 01^{\prime} 59.9^{\prime \prime} \mathrm{W}\right)$ and Salto

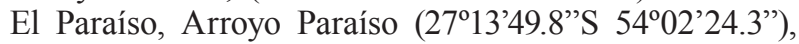
department of Guaraní, 27 A. montensis and three Sooretamys angouya (Fischer 1814) from Refugio Moconá (27ㅇ' $\left.29.01^{\prime \prime} S 53^{\circ} 55^{\prime} 40.44^{\prime \prime} \mathrm{W}\right)$, department of San Pedro, province of Misiones, 16 Akodon azarae bibianae Massoia 1971, 10 Calomys callosus Rengger 1830, and three Necromys lasiurus liciae Contreras 1982 from Reserva El Bagual (26 $\left.18^{\circ} 12.81^{\prime \prime} \mathrm{S} 58^{\circ} 48^{\prime} 51.57^{\prime \prime} \mathrm{W}\right)$, department of Laishi and Estación de Animales Silvestres Guaycolec, Ruta Nacional 11, km 1201 (2558'40.65”S 58 09'49.82”), department of Formosa, province of Formosa.

The viscera (included lungs) were fixed whole in $10 \%$ buffered formalin and examined. Pulmonary arteries and veins were opened and observed for adult worms using a stereoscopic microscope. Adult nematodes were collected, preserved in $70 \%$ ethanol, cleared in lactophenol, and studied under a light microscope. Drawings were made with the aid of a drawing tube. Each of the five lobes of the lungs was trimmed in the subterminal transversal part, processed, sectioned at $5 \mu \mathrm{m}( \pm 25 \mathrm{sec}-$ tions per slide), stained with haematoxylin and eosin (H\&E), and examined microscopically.
Quantitative parameters of prevalence $(\mathrm{P}=$ specimens parasitised/specimens examined x 100) was calculated according to Bush et al. (1997) for each host species and locality.

Records of species of Angiostrongylus from rodents were compiled from the literature (scientific papers and book sections). When necessary, scientific names of mammal hosts have been updated following Edwards et al. (1993), Wilson and Reeder (2005), Weksler et al. (2006), and Srinivasulu and Srinivasulu (2011). In order to evaluate host specificity, the specificity index $\left(\mathrm{S}_{\mathrm{TD}}\right)$ by Poulin and Mouillot (2003) was calculated. This index measures the average taxonomic distinctness of all host species used by a parasite species. All mammal species included were fitted into a taxonomic structure with six hierarchical levels above species, i.e., genus, subfamily, family, superfamily, order, and class (Mammalia). The range of index can vary between 1-6, and since the index cannot be computed for parasites exploiting a single host species, the value of zero is assigned to reflect strict host specificity. The value of this index is inversely proportional to host specificity. The asymmetries in the taxonomic distribution of host species were calculated through variance in taxonomic distinctness $\left(\operatorname{VarS}_{\mathrm{TD}}\right)$ (Poulin \& Mouillot 2003). A record was defined as the finding of a parasite species on a definitive host and, at a given locality, regardless of the number of host sampled and of nematodes collected on a particular host. The aberrant host species reported (Maldonado et al. 2012, Spratt 2015) which showed signs of disease were included in the calculation of host specificity, but not the experimentally infected or accidental host species.

Adult specimens and H\&E stained sections (slides) of lung were deposited in the Helminthological Collection of the Museo de La Plata (CHMLP A. costaricensis 7052 and A. morerai 7053-7059, respectively) and the hosts were deposited in the Mastozoological Collections of the Centro Nacional Patagónico (CNP 1968, 2338, 3004, 3723, 4079, 4080, 4027, 4602, field number CG 70, 78, RR 33), Puerto Madryn, Chubut, Argentina.

Ethics - The research has been conducted according to Argentine laws. Sample collection was carried out during fieldwork under official permits granted by Fauna and Flora of the Province of Buenos Aires (expedient 22500-7981/10), Ministry of Industry and Environment of the Province of Formosa (authorisation $n / n$; transit guide: 004076), Ministry of Ecology, Renewable Natural Resources, and Tourism of Misiones (authorisation 24 and 27, transit guides: 000316 and 000371). This study was carried out in accordance with the recommendations in the Guide for the Care and Use of Laboratory Animals of the National Institutes of Health. The specimens obtained with methods for live capture were studied and humanely sacrificed following the procedures and protocols approved by national laws (Animal Protection National law 14.346 and references in the provincial permits) and Ethical Committee for Research on Laboratory Animals, Farm, and Obtained from Nature of National Council of Scientific and Technical Research (resolution 1047, section 2, annex II), and subsequently 
A

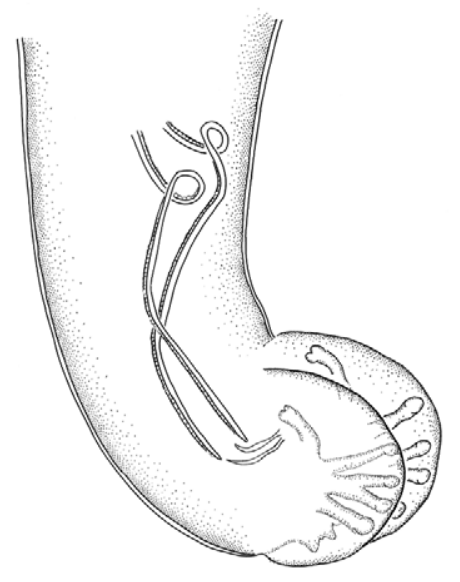

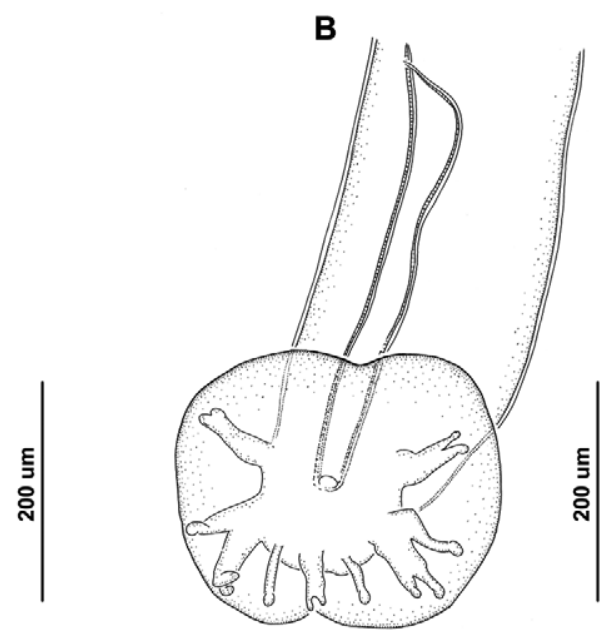

Fig. 1: male adult specimens of Angiostrongylus spp. A: Angiostrongylus costaricensis from caecal mesenteric arteries of Akodon montensis of the province of Misiones, medium lateral view; B: Angiostrongylus morerai from the lungs and heart from Calomys callosus of the province of Formosa, ventral view.

TABLE I

Prevalence of Angiostrongylus spp for each host species and locality

\begin{tabular}{|c|c|c|c|}
\hline Host species & Locality & $\begin{array}{l}\text { Prevalence } \\
\text { by population } \\
\text { (\%) }\end{array}$ & $\begin{array}{l}\text { Prevalence } \\
\text { by ecoregion } \\
(\%)\end{array}$ \\
\hline \multicolumn{4}{|l|}{ Angiostrongylus costaricensis } \\
\hline Akodon montensis & Arroyo Paraíso & 1/11 (9) & Selva Paranaense (9) \\
\hline \multicolumn{4}{|l|}{ Angiostrongylus morerai } \\
\hline \multirow[t]{2}{*}{ Deltamys kempi } & La Balandra & $1 / 4(25)$ & La Pampa (62.5) \\
\hline & Reserva Natural de la Costanera Sur & $4 / 4(100)$ & \\
\hline A. montensis & Refugio Moconá & $4 / 27(14.8)$ & Selva Paranaense (20) \\
\hline Sooretamys angouya & Refugio Moconá & 2/3 (66) & \\
\hline Akodon azarae bibianae & Reserva El Bagual & 2/11 (18.18) & Chaco Húmedo (17.4) \\
\hline Calomys callosus & Reserva El Bagual & $1 / 10(10)$ & \\
\hline Necromys lasiurus liciae & Reserva El Bagual & $1 / 2(50)$ & \\
\hline
\end{tabular}

by National Agency for the Promotion of Science and Technology of Argentina (PICT 2010-0924). No endangered species were involved in this study.

\section{RESULTS}

A single male specimen of Angiostrongylus found in the caecal mesenteric arteries of $A$. montensis from El Soberbio was identified as A. costaricensis. Adult specimens found in the pulmonary arteries and heart of D. kempi from La Balandra and Reserva Natural de la Costanera Sur, A. montensis and S. angouya from Refugio Mocona, and A. azarae, C. callosus, and N. lasiurus from Reserva El Bagual were identified on the basis of the morphology of the bursa, spicules, and diagnostic measurements as $A$. morerai (Fig. 1).

Table I lists prevalence of infections for all hosts examined. The prevalence of $A$. costaricensis was very low $(9 \%)$. The highest prevalence of $A$. morerai was recorded in D. kempi. The region with the most records of this nematode was La Pampa ecoregion $(\mathrm{P}=62.5 \%)$ in the province of Buenos Aires. The Selva Paranaense (province of Misiones) and Chaco Húmedo (province of Formosa) ecoregions showed similar values ( $\mathrm{P}=20 \%$ and $17.4 \%$, respectively) (Table I). 

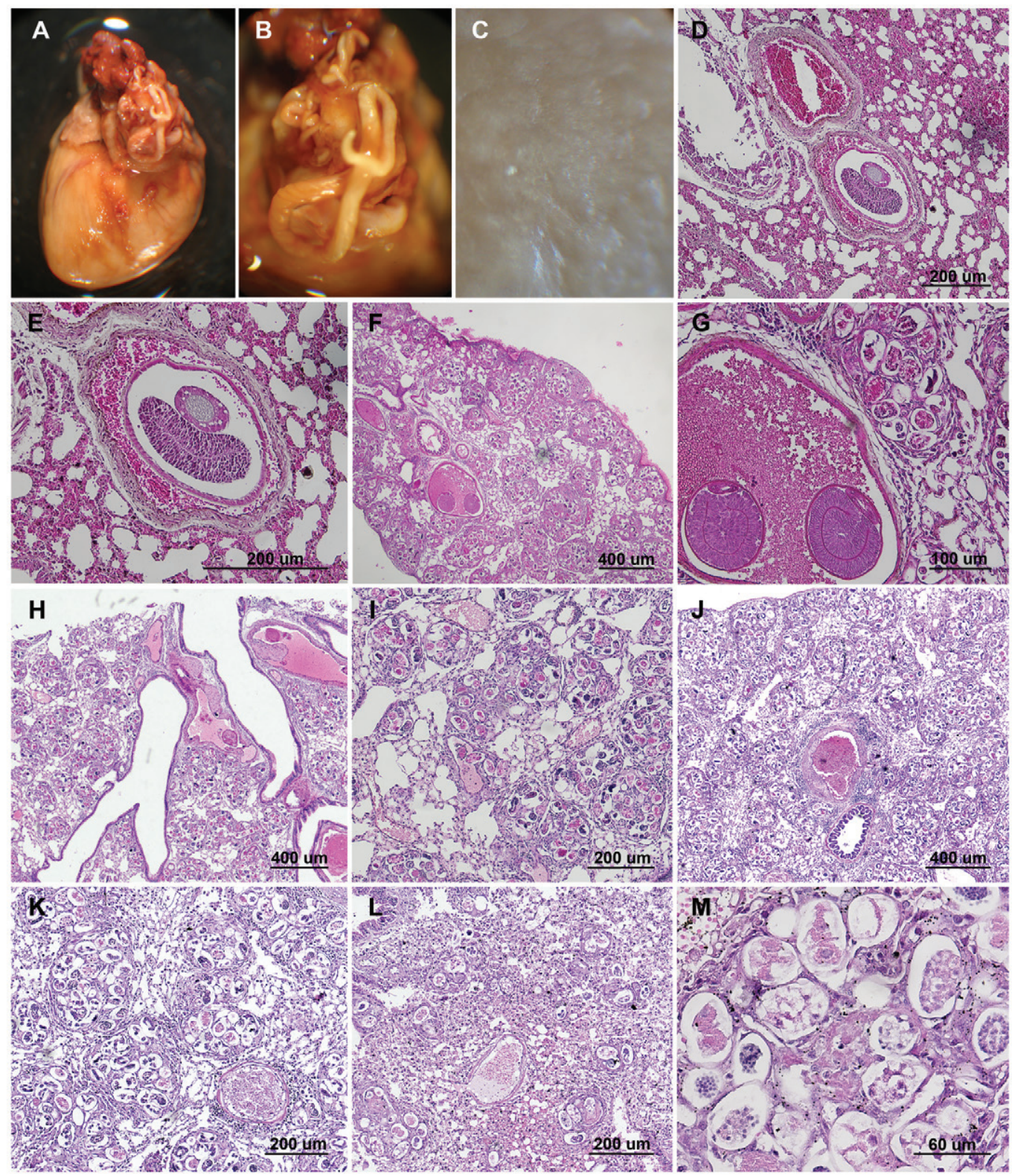

Fig. 2: macroscopic and histopathological examination of heart and lung infected with Angiostrongylus morerai. A: adult specimen in pulmonary artery of Akodon azarae; B: detail of female specimen in pulmonary artery; C: lung with macroscopic lesions (firm nodules) of verminous pneumonia; D: lungs of Deltamys kempi with detail of the interior of a blood vessel containing adult worm; E: detail of adult worm; F: lungs of Akodon montensis with superficial interstitium and alveoli containing eggs, larvae, and adult worm; G: detail of eggs, larvae, and adult worm in interior of a blood vessel; $\mathrm{H}$ : lungs of $A$. azarae with detail of interstitium, alveoli, and vessels contained nematode eggs and larvae; I: detail of granulomatous inflammatory reactions, vessel, and interstitium contained eggs and nematode larvae; J: lungs of Calomys callosus with superficial interstitium and alveoli containing nematode larvae; K: detail of granulomatous inflammatory reactions surround each set of eggs and larvae; L: lungs of Necromys lasiurus with interstitium, alveoli, and vessels contained nematode eggs and larvae; M: granulomatous inflammatory reactions, vessel, and interstitium contained eggs on different embryonic stages and nematode larvae.

Specimens of A. morerai were present in heart chambers (Fig. 2A) and in pulmonary arteries sometimes showing the complete obliteration of the lumen (Fig. 2B). The infected rodents showed macroscopic lesions (firm nodules) of verminous pneumonia in three, four, or five lobes. Each lung lobe contained multiple small yellowish nodules scattered throughout the parenchyma (Fig. 2C).
Additionally, histopathology examination of tissue fragments showed multiple nodules in the vessels, interstitium, and alveoli. Nodules were formed by larvae surrounded by an elevated number of granulocyte and mononuclear cells (Fig. 2M). The vessels, interstitium, and alveoli contained nematode larvae with mild to moderate interstitial fibrosis (Fig. 2F-M). Worms were 


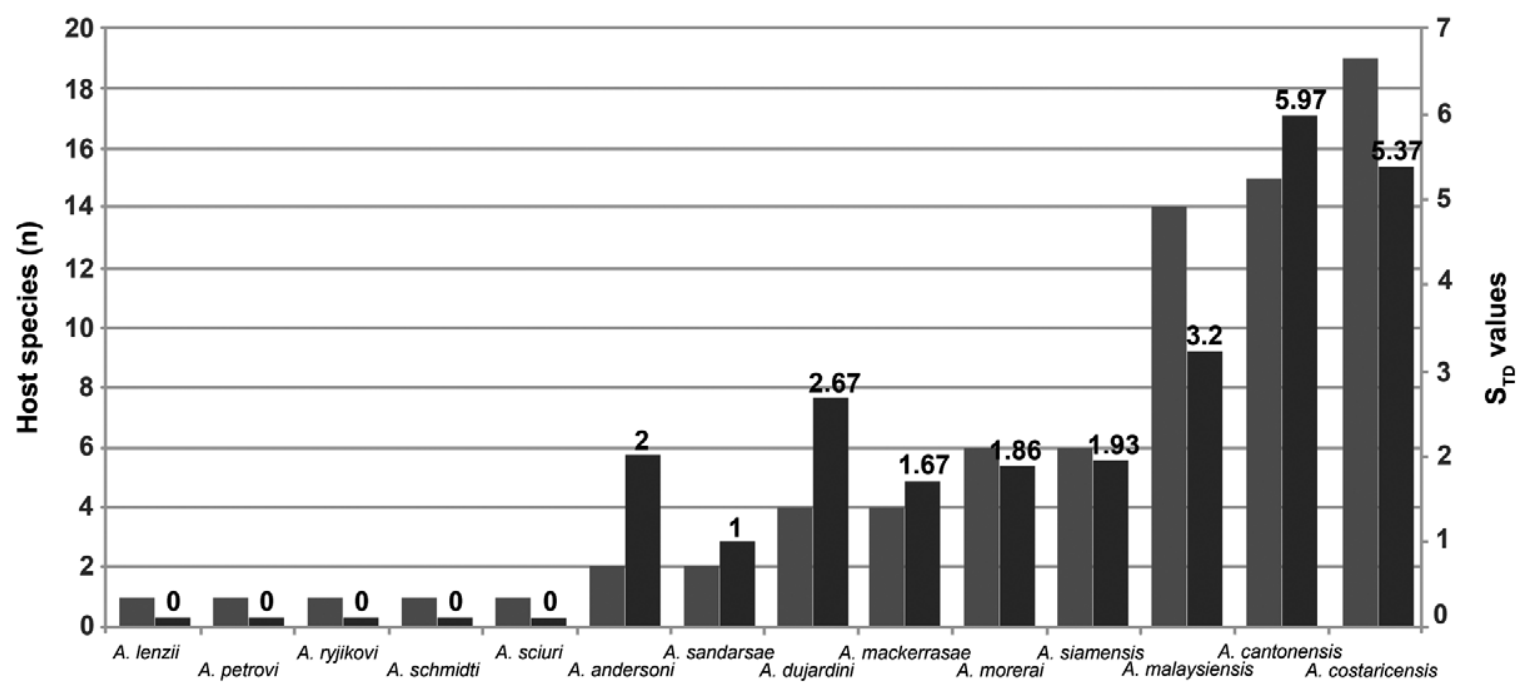

Fig. 3: number of host species (left) and host specificity values (right) for Angiostrongylus species from rodents. $\mathrm{S}_{\mathrm{TD}}$ specificity index.

approximately $80-200 \mu \mathrm{m}$ long and contained numerous discrete basophilic and eosinophilic granules (Fig. M). Numerous nodules (set of eggs and larvae) surround by granulomatous reactions were situated under the pleural surface (Fig. 2F, J). Several damaged capillaries and small arterioles were observed (Fig. 2D-H).

The lobe with the greatest intensity of larvae proportionally was the left upper followed by the right lower and right medium lobes, the right upper and left lower lobes, had similar, but smaller, intensities of infection. As estimation about one-five larvae per $200 \mu \mathrm{m} 2$ x 5 $\mu \mathrm{m}$ thickness could be observed in the left upper lobe. In the other lobes, the nodules were more scattered. The host with the most nodules (set of larvae) surrounded by granulomatous reactions was C. callosus (Fig. 2J, K).

Number of host species for all Angiostrongylus species found in rodents and values of $\mathrm{S}_{\mathrm{TD}}$ and $\operatorname{Var} \mathrm{S}_{\mathrm{TD}}$ for each species are shown in Table II and depicted in Fig. 3. The distribution of number of host species was skewed considering only the natural infection by angiostrongylosis (Fig. 3). The figures clearly show that most Angiostrongylus species parasitise between one-19 different host species: five Angiostrongylus species were associated with a single species, $A$. andersoni and $A$. sandarsae were found in two host species, A. dujardini and A. mackerrasae in four host species, A. morerai and A. siamensis in six host species, and the rest in more than 10 host species. The values of $S_{T D}$ were between 1-5.97. The value of zero was assigned for five species to reflect the strict host specificity. A. andersoni, A. sandarsae, A. mackerrasae, A. morerai, and $A$. siamensis parasitise species hosts that belong to different subfamilies $\left(\mathrm{S}_{\mathrm{TD}}=1-2\right), A$. dujardini to different families ( $\left.\mathrm{S}_{\mathrm{TD}}=2-3\right)$, A. malaysiensis to different superfamilies $\left(\mathrm{S}_{\mathrm{TD}}=3-4\right)$, and A. cantonensis and A. costaricensis to different orders $\left(\mathrm{S}_{\mathrm{TD}}=5-6\right)$.

\section{DISCUSSION}

This is the first record of A. morerai from A. montensis, C. callosus, D. kempi, N. lasiurus, and S. angouya expanding its geographic distribution to the south and northwest of the provinces of Buenos Aires, Misiones, and Formosa. A. costaricensis is recorded for first time in A. montensis and in Argentina. The presence of Angiostrongylus spp in these hosts indicates the ingestion of unknown intermediate hosts, which are apparently frequent in the diet of rodents of the tribe Akodontini (e.g., Akodon, Necromys, Deltamys).

With respect to the gross and histopathologic changes in the lungs of the host species, a different degree of pathogenicity was observed among the hosts, with the highest being in C. callosus (Phyllotini). This is the first record of Angiostrongylus sp. in this tribe of sigmodontine rodents. As demonstrated in Robles et al. (2012), in A. morerai, the resulting immune reaction can cause interstitial fibrosis and the destruction of small capillaries and arterioles. In that study and here, extensive lesions were apparently caused by a single male and female (Fig. 2A, B). Macroscopic lesions of verminous pneumonia in the lungs were similar to those described for A. mackerrasae by Mackerras and Sandars (1955) and A. sandarsae by Alicata (1968). Histopathological examination revealed nodules formed as a result of larvae being surrounded by granulocytes and mononuclear cells (Fig. 2C-M).

Of the 15 species of Angiostrongylus parasitic in rodents, detailed descriptions of histopathologic changes are available for seven (A. cantonensis, $A$. costaricensis, A. mackerrasae, A. morerai, A. sandarsae, A. siamensis, and $A$. schmidti) and the life cycles of eight species have been studied (A. andersoni, A. cantonensis, A. costaricensis, A. dujardini, A. mackerrasae, A. malaysiensis, A. siamensis, and A. schmidti) (Mackerras \& Sandars 1955, Ali- 


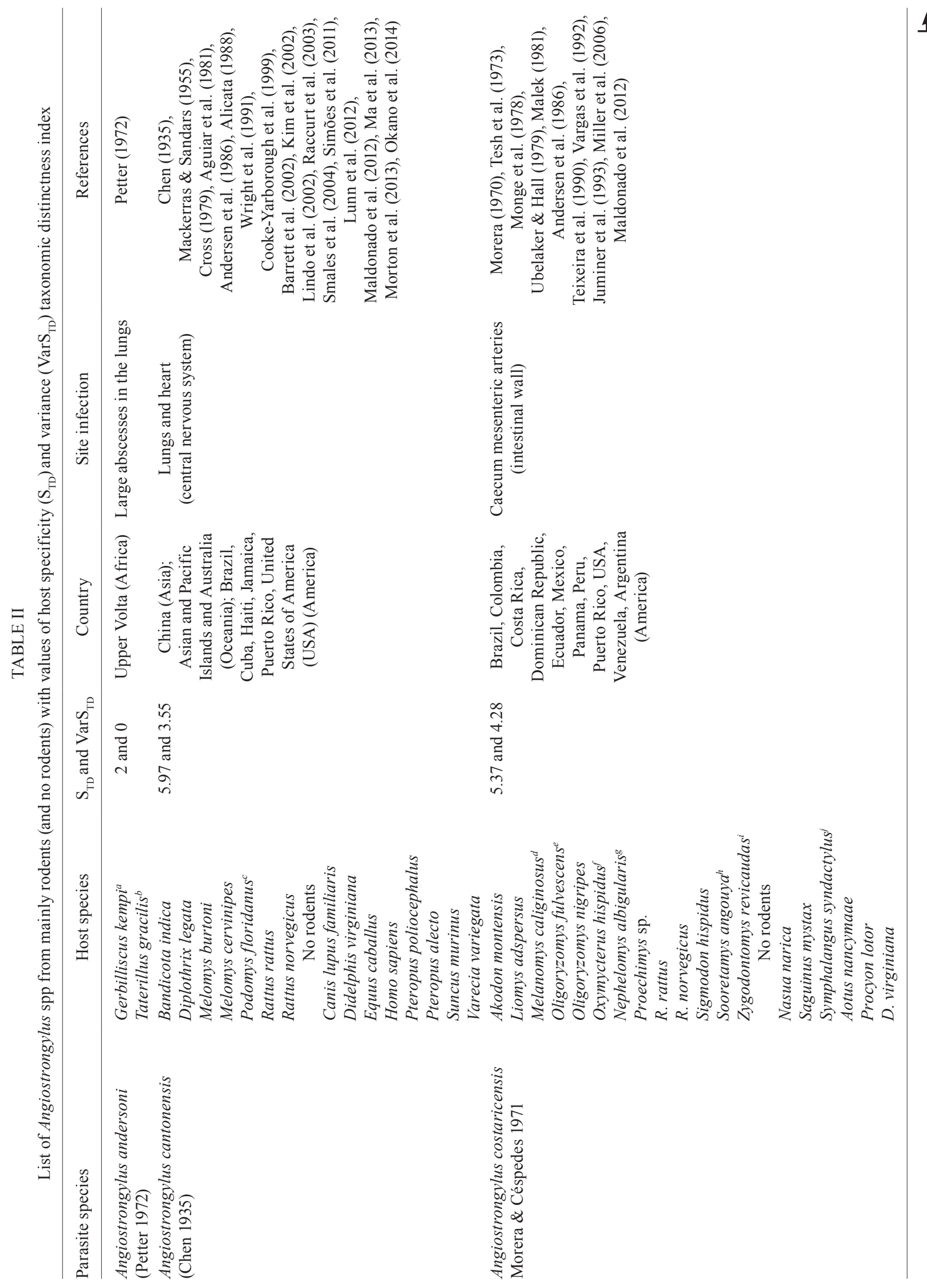




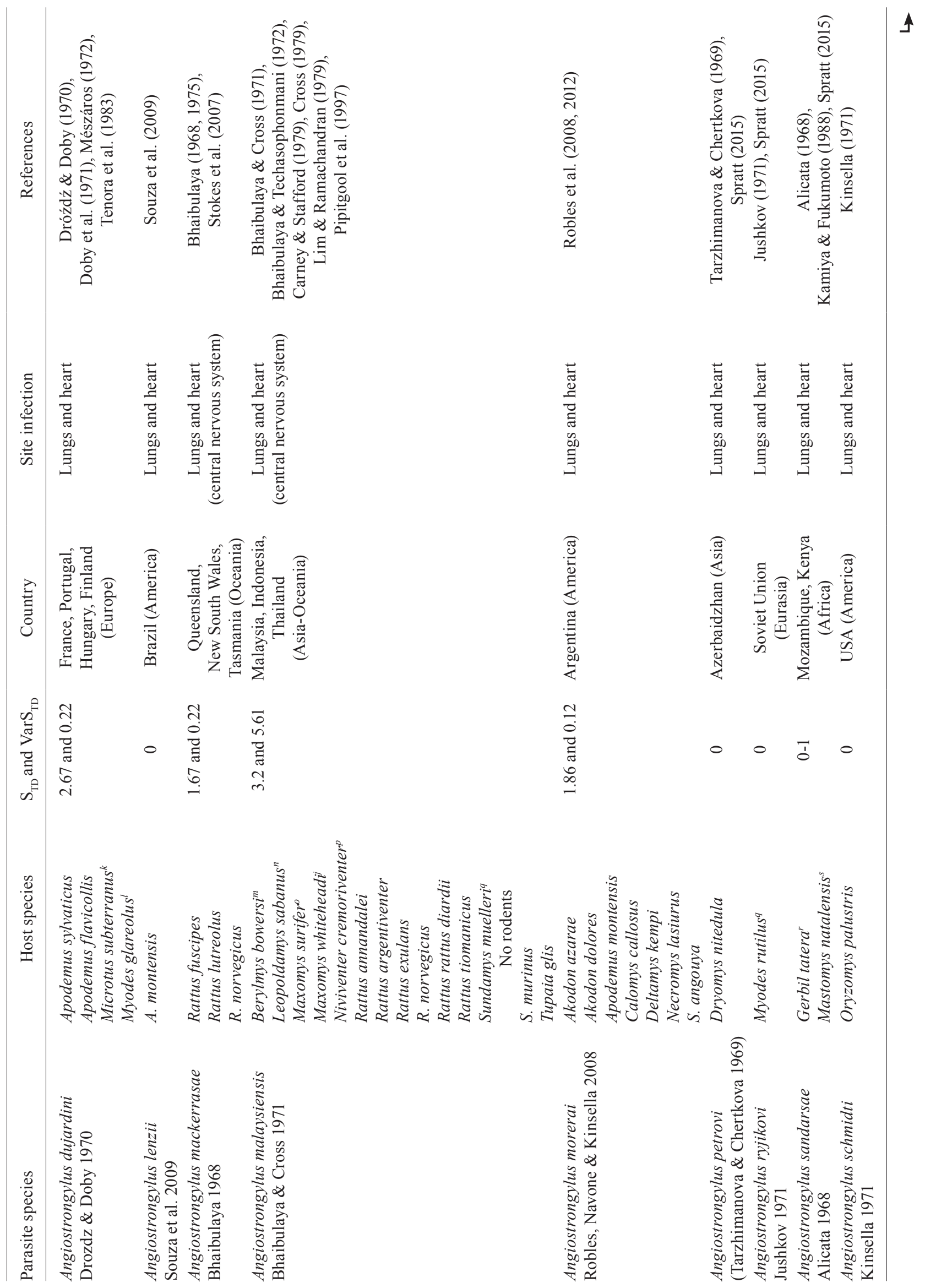




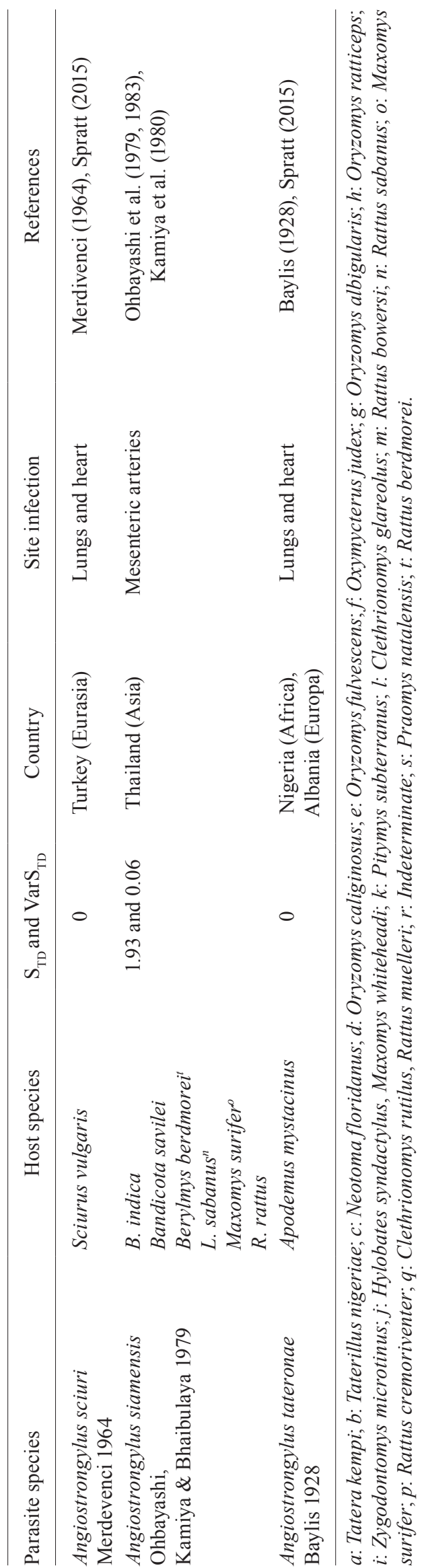

cata 1968, Kinsella 1971, Bhaibulaya 1975, Mota \& Lenzi 2005, Robles at al. 2012). However, to know the complete pathogenicity and potential transmission of each parasitic species, studies on intermediate hosts and the reaction of the larvae in the affected organs must be completed.

The presence of $A$. morerai in Argentina in different ecoregions indicates that environmental features may have little influence on geographic distribution, although it is interesting to note that apparently these can influence frequency and abundance. Prevalence in the La Pampa ecoregion was considerably higher than Selva Paranaense (20\%) and Chaco Húmedo (17.4\%). The question is whether the differences in the frequency and abundance of Angiostrongylus spp may be due to the sampling effort and/or to the distribution of definitive and intermediate hosts and/or to the susceptibility of both. For example, with respect to the latter, Combes (2001) proposed different filters of parasite-host association; encounter filters (biodiversity and behaviour) and compatibility filters (resource and density).

Five species of Angiostrongylus have been reported in North and South American rodents: A. cantonensis, $A$. costaricensis, A. lenzii, A. morerai, and A. schmidti. Notably, the snails Achatina fulica (Bowdich 1822), Pomacea caniculata (Lamarck 1828), Phyllocaulis variegatus (Semper 1885), Phyllocaulis soleiformis (Orbigny 1835), Belocaulus angustipes (Heynemann 1885) are recorded from the area studied in this survey, and have all been previously recorded as intermediate hosts of $A$. cantonensis and/or A. costaricensis (Teixeira et al. 1993, Díaz et al. 2013, Gregoric et al. 2013). Accordingly, the low host specificity of these Angiostrongylus spp it is puzzling that there been no cases of eosinophilic meningoencephalitis or abdominal angiostrongylosis in Argentina to date. Spratt (2015) partly answer to a similar situation, since the reports in the literature of many species of Angiostrongylus in rodents reflect lack of opportunity or interest in examining nonurban and nonagricultural hosts (Table II).

The elevated number of host species $(\mathrm{n}=7)$ of $A$. morerai with a $\mathrm{S}_{\mathrm{TD}}=1.86$ is a reflection of multiple systematic studies of parasites from sigmodontine rodents in the area of Cuenca del Plata Argentina, showing that an increase in sampling effort can result in new findings. Therefore, a low number of host species used by other Angiostrongylus species may be an artifact caused by lack of sampling effort.

This is the first attempt to describe general patterns of host specificity of Angiostrongylus from rodents through a quantitative approach. Host specificity values did not include the hosts recorded as part of experimental infections or accidental hosts (Table II). Those hosts include Taterillus cf. congicus for A. andersoni, Aepyprymnus rufescens and Macropus rufogriseus for A. cantonensis, Pteropus alecto for A. mackerrasae, Meriones unguiculatus, Mesocricetus auratus, Mus musculus, Peromyscus leucopus, Rattus norvegicus, and Sigmodon hispidus for A. schmidti (Kinsella 1971, Petter \& Cassone 1975, McKenzie et al. 1978, Higgins et al. 1997, Barrett et al. 2002). However, those studies support the conclusions of this survey, since the addition of hosts from other families and orders would only increase the $\mathrm{S}_{\mathrm{TD}}$ values. 
In conclusion, the distribution of Angiostrongylus spp shows no environmental limits, demonstrates low host specificity, and indicates that their host range has probably been underestimated. In addition, there are other host records of some species of Angiostrongylus which need to be confirmed by morphological and molecular analysis (Robles et al. 2012). Moreover, it is necessary to explore the different degrees of pathogenicity in various hosts, mainly in those cases that are phylogenetically more distant (different host family) to analyse which are the filters (meeting, immunological, etc.) that determine host distribution. These results would allow anticipating contingencies and prevention planning for diseases caused by angiostrongylosis.

There is a need to increase awareness in the human population about the risk of contracting angiostrongyliasis and healthcare providers should consider these parasites on the South American continent when making medical diagnoses. Moreover, surveillance and control of intermediate and definitive hosts as well as health education should be done to avoid human infections.

\section{ACKNOWLEDGEMENTS}

To Emilio Topa, for helping in the preparation of the tissue fragments (slides), to María Cristina Estivariz, for the drawings, to Ulyses Pardiñas, Marcela Lareschi, Juliana Notarnicola, Guillermo Panisse, and Olga Suarez, for cooperation in the field tasks and host collections, to Ulyses Pardiñas and Pablo Teta, for the identification of the hosts, and to Ulyses Pardiñas, for critical reading.

\section{REFERENCES}

Acha P, Szyfres B 2003. Zoonoses and communicable diseases man and animals, 3rd ed., Pan American Health Organization, Scientific and Tech Publications, Washington DC, 404 pp.

Aguiar PH, Morera P, Pascual JE 1981. First record of Angiostrongylus cantonensis in Cuba. Am J Trop Med Hyg 30: 963-965.

Alicata JE 1968. Angiostrongylus sandarsae sp. n. (Nematoda: Metastrongyloidea), a lungworm of rodents in Mozambique, East Africa. J Parasitol 54: 896-899.

Alicata JE 1988. Angiostrongylus cantonensis (eosinophilic meningitis): historical events in its recognition as a new parasitic disease of man. J Wash Acad Sci 78: 38-46.

Andersen E, Gubler DJ, Sorenson K, Beddard J, Ash LR 1986. First report of Angiostrongylus cantonensis in Puerto Rico. Am J Trop Med Hyg 35: 319-322.

Baillet CC 1866. Strongyle des vaisseaux et du Coeur du chien. Strongylus vasorum (Nobis). Nouveau Dictionnaire Practique de Médecine, de Chirurgie et d'Hygiène Vétérinaires 8: 587-588.

Barrett JL, Carlisle MS, Prociv P 2002. Neuro-angiostrongylosis in wild black and grey-headed flying foxes (Pteropus spp). Aust Vet J 80: 554-558.

Baylis HA 1928. On a collection of nematodes from Nigerian mammals, chiefly rodents. Parasitology 20: 280-304.

Bhaibulaya M 1968. A new species of Angiostrongylus in an Australian rat, Rattus fuscipes. Parasitology 58: 789-799.

Bhaibulaya M 1975. Comparative studies of the life history of Angiostrongylus mackerrasae Bhaibulaya, 1968 and A. cantonensis (Chen, 1935). Int J Parasitol 5: 7-20.
Bhaibulaya M, Cross JH 1971. Angiostrongylus malaysiensis (Nematoda: Metastrongylidae), a new species of rat lung-worm from Malaysia. Southeast Asian J Trop Med Public Health 2: 527-533.

Bhaibulaya M, Techasophonmani V 1972. Mixed infections of Angiostrongylus spp in rats. Southeast Asian J Trop Med Public Health 3: 451.

Biocca E 1957. Angiostrongylus chabaudi n. sp. parassita del cuore e dei vasi polmonari del gatto selvatico (Felis silvestris). Atti Accad Naz Lincei 22: 526-532.

Bush AO, Lafferty KD, Lotz JM, Shostak AW 1997. Parasitology meets ecology on its own terms: Margolis et al. revisited. J Parasitol 83: 575-583.

Carney WP, Stafford EE 1979. Angiostrongyliasis in Indonesia - a review. In JH Cross (ed.), Studies on angiostrongyliasis in eastern Asia and Australia, NAMRU-2 Special Publication 44, US Naval Medical Research Unit, Taiwan, p. 14-25.

Chen HT 1935. A new pulmonary nematode of rats, Pulmonema cantonensis n. g, n. sp. from Canton. Ann Parasitol Hum Comp 13: 312-317.

Combes C 2001. Parasitism: the ecology and evolution of intimate interactions, University of Chicago Press, Chicago and London, 728 pp.

Cooke-Yarborough CM, Kornberg AJ, Hogg GG, Spratt DM, Forsyth JRL 1999. A fatal case of angiostrongyliasis in an 11 month old infant. Med J Aust 170: 541-543.

Cross JH 1979. Studies on angiostrongyliasis in Eastern Asia and Australia, NAMRU-2 Special Publication 44, US Naval Medical Research Unit, Taiwan, 164 pp.

Díaz JI, Lorenti E, Valente R, Capasso S, Gregoric DG, Navone GT 2013. Estado actual del conocimiento de las parasitosis del molusco invasor Achatina fulica en la Argentina su importancia como posible vector de angiostrongiliasis. In OE Salomón, A Rumi (eds.), Moluscos de interés sanitario en la Argentina, INMeT, Puerto Iguazú, p. 40-53.

Dick CW, Patterson BD 2007. Against all odds: explaining high host specificity in dispersal-prone parasites. Int J Parasitol 37: 871-876.

Doby JM, Piedade-Guerreiro J, Dróźdź J 1971. Répartition géographique de Angiostrongylus (Parastrongylus) dujardini Dróźdź et Doby, 1970 nématode parasite des petits rongeurs sauvages. Présence au Portugal. An Esc Nac Saude Publ Med Trop (Lisboa) 5: 59-60.

Dougherty EC 1946. The genus Aelurostrongylus Cameron, 1927 (Nematoda: Metastrongylidae) and its relatives; with descriptions of Parafilaroides gen. nov., and Angiostrongylus gubernaculatus sp. nov. Proc Helminthol Soc Wash 13: 16-26.

Dróźdź J, Doby JM 1970. Angiostrongylus dujardini sp. n. (Nematoda: Metastrongyloidea) parasite de Apodemus sylvaticus et Clethrionomys glareolus. B Soc Zool Fr 95: 659-668.

Edwards DS, Booth WE, Choy SC 1993. Tropical rainforest research - Current issues: Proceedings of the Conference Held in Bandar Seri Begawan, April 1993 (Monographiae Biologicae), Springer Netherlands, $566 \mathrm{pp}$.

Gregoric DEG, Núñez MV, Vogler R, Beltramino AA, Rumi A 2013. Gasterópodos terrestres de la provincia de Misiones, Argentina. Rev Biol Trop 41: 1759-1768.

Higgins DP, Carlisle-Nowak MS, Mackie J 1997. Neural angiostrongylosis in three captive rufous bettongs (Aepyprymnus rufescens). Aust Vet J 75: 564-566.

Juminer B, Borel G, Mauleon H, Durette-Desset M, Raccurt C, Roudier M, Nicolás M, Péres J 1993. Natural murine infestation by Angiostrongylus costaricensis Morera and Céspedes, 1971, in Guadaloupe. Bull Soc Pathol Exot 86: 502-505. 
Jushkov VF 1971. Angiocaulus ryjikovi sp. n. (Nematoda: Strongylata), a parasite of the northern redbacked vole (Clethrionomys rutilus Pallas) from northern Ural. Parazitologiva 4: 344-346.

Kamiya M, Fukumoto S 1988. Angiostrongylus sandarsae Alicata, 1968 (Nematoda: Metastrongyloidea) from Praomys natalensis in Kenya. Jpn J Vet Res 36: 47-52.

Kamiya M, Oku Y, Kamiya H, Ohbayashi M, Abe H, Suzuki H 1980. Report on the prevalence and experimental infections of Angiostrongylus siamensis Ohbayashi, Kamiya et Bhaibulaya, 1979, parasitic in the mesenteric arteries of rodents in Thailand. Jpn $J$ Vet Res 28: 114-121.

Kim DY, Stewart TB, Bauer RW, Mitchell M 2002. Parastrongylus (= Angiostrongylus) cantonensis now endemic in Louisiana wildlife. J Parasitol 88: 1024-1026.

Kinsella JM 1971. Angiostrongylus schmidti sp. n. (Nematoda: Metastrongyloidea) from the rice rat, Oryzomys palustris, in Florida, with a key to the species of Angiostrongylus Kamensky, 1905. $J$ Parasitol 57: 494-497.

Lim BL, Ramachandran CP 1979. Ecological studies on Angiostrongylus malaysiensis (Nematoda: Metastrongylidae) in Malaysia. In JH Cross (ed.), Studies on angiostrongyliasis in Eastern Asia and Australia, NAMRU-2 Special Publication 44, US Naval Medical Research Unit, Taiwan, p. 26-48.

Lindo J, Waugh C, Hall J, Cunningham-Myrie C, Ashley D, Eberhard M 2002. Enzootic Angiostrongylus cantonensis in rats and snails after outbreak of human eosinophilic meningitis in Jamaica. Emerg Infect Dis 8: 324-326.

Lunn JA, Lee R, Smaller J, MacKay BM, King T, Hunt GB 2012. Twenty-two cases of canine neural angiostronglyosis in eastern Australia (2002-2005) and a review of the literature. Parasit Vectors 5: 70.

Ma G, Dennis M, Rose K, Spratt D, Spielman D 2013. Tawny frogmouths and brushtail possums as sentinels for Angiostrongylus cantonensis, the rat lungworm. Vet Parasitol 192: 158-165.

Mackerras MJ, Sandars DF 1955. The life history of the rat lung-worm Angiostrongylus cantonensis (Chen) (Nematoda: Metastrongylidae). Aust J Zool 3: 1-21.

Maldonado A, Simões R, Thiengo SC 2012. Angiostrongyliasis in the Americas. In J Lorenzo-Morales (ed.), Zoonosis, In Tech, Rijeka, p. 303-320.

Malek E 1981. Presence of Angiostrongylus costaricensis Morera and Cépedes, 1971 in Colombia. Am J Trop Med Hyg 30: 81-83.

McKenzie RA, Green PE, Wood AD 1978. Angiostrongylus cantonensis infection of the brain of a captive Bennett's wallaby (Macropus rufogriseus). Aust Vet $J$ 54: 86-88.

Merdivenci A 1964. A new lungworm, Angiostrongylus sciuri n. sp. parasitising in the venae pulmonales of the squirrel, Sciurus vulgaris. Istanb Univ Fen Fak Mecm 29: 155-158.

Mészáros F 1972. The occurrence of Angiostrongylus (P.) dujardini Drozdz et Doby, 1970 (Nematoda) in rodents in Hungary. Parasit Hung 5: 163-176.

Miller CL, Kinsella JM, Garner MM, Evans S, Gullett PA, Schmidt RE 2006. Endemic infections of Parastrongylus (= Angiostrongylus) costaricensis in two species of nonhuman primates, raccoons, and an opossum from Miami, Florida. J Parasitol 92: 406-408.

Monge E, Arroyo R, Solano E 1978. A new definitive natural host of Angiostrongylus costaricensis (Morera and Céspedes, 1971). J Parasitol 64: 34

Morera P 1970. Investigación del huésped definitivo de Angiostrongylus costaricensis (Morera y Céspedes, 1971). Boletin Chileno de Parasitologia Santiago 25: 133-134.
Morera P, Céspedes R 1971. Angiostrongylus costaricensis n. sp. (Nematoda: Metastrongyloidea), a new lungworm occurring in man in Costa Rica. Rev Biol Trop 18: 173-185.

Morton NJ, Britton P, Palasanthiran P, Bye A, Sugo E, Keeson A 2013. Severe haemorrhagic meningoencephalitis due to Angiostrongylus cantonensis among young children in Sydney, Australia. Clin Infect Dis 57: 1158-1161.

Mota EM, Lenzi HL 2005. Angiostrongylus costaricensis: complete redescription of the migratory pathways based on experimental Sigmodon hispidus infection. Mem Inst Oswaldo Cruz 100: 407-420.

Ohbayashi M, Kamiya M, Bhaibulaya M 1979. Studies on the parasite fauna of Thailand I. Two new metatsrongylid nematodes, Angiostrongylus siamensis $\mathrm{sp} . \mathrm{n}$. and Thaistrongylus harinasutai gen. et $\mathrm{sp}$. (Metastrongyloidea; Angiostrongylidae) from wild rats. Jpn J Vet Res 27: 5-10.

Ohbayashi M, Machida M, Kamiya H, Yuzaburo O, Abe H, Klongkamnuankarn K 1983. Incidence of Angiostrongylus siamensis in small mammals at Nakorn Nayok, Thailand. Jpn J Vet Res 31: 49-50.

Okano T, Haga A, Mizuno E, Onuma M, Nakaya Y, Nagamine T 2014. Angiostrongylus cantonensis (Nematoda: Metastrongylidae) in the Ryukyu Islands tree rat (Diplothrix legata). $J$ Wildl Dis 50: 322-325.

Petter AJ 1972. Description d'une nouvelle espèce d'Aelurostrongylus parasite de rongeur africain. Ann Parasitol Hum Comp 47: 131-137.

Petter AJ, Cassone J 1975. Mode de pénétration et localisation des larves de Morerastrongylus andersoni (Petter, 1972) (Metastrongyloidea, Nematoda) chez l'hôte intermédiare. Ann Parasitol Hum Comp 50: 469-475.

Pipitgool V, Sithithaworn P, Pongmuttasaya P, Hinz E 1997. Angiostrongylus infections in rats and snails in northeast Thailand. Southeast Asian J Trop Med Public Health 28: 190-193.

Poulin R 2007. Evolutionary ecology of parasites, 2nd ed., Princeton University Press, Princeton, $332 \mathrm{pp}$.

Poulin R, Mouillot D 2003. Parasite specialization from a phylogenetic perspective: a new index of host specificity. Parasitology 126: 473-480.

Raccurt C, Blaise J, Durette-Desset M2003. Présence d'Angiostrongylus cantonensis en Haiti. Trop Med Int Health 8: 423-426.

Robles MR, Navone GT, Kinsella JM 2008. A new angiostrongylid (Nematoda) species from the pulmonary arteries of Akodon azarae (Rodentia: Cricetidae) in Argentina. J Parasitol 94: 515-519.

Robles MR, Perfumo CJ, Kinsella JM, Navone GT 2012. Angiostrongylus morerai from Akodon species (Rodentia: Sigmodontinae) from Sierra de la Ventana, Buenos Aires, Argentina: histopathological and parasitological studies. J Parasitol 98: 1133-1138.

Simões RO, Souza JGR, Maldonado Jr A, Luque JL 2011. Variation in the helminth community structure of three sympatric sigmodontine rodents from the coastal Atlantic Forest of Rio de Janeiro, Brazil. J Helminthol 85: 171-178.

Smales LR, Heinrich B, McKillup SC 2004. The helminth parasites of Melomys cervinipes (Rodentia: Muridae: Hydromyinae). Aust J Zool 52: 65-80.

Souza JGR, Simoés RO, Thiengo SARC, Lima WS, Mota EM, Rodrigues-Silva R 2009. A new metastrongylid species (Nematoda: Metastrongylidae): a lungworm from Akodon montensis (Rodentia: Sigmodontinae) in Brazil. J Parastiol 95: 1507-1511.

Spratt DM 2015. Species of Angiostrongylus (Nematoda: Metastrongyloidea) in wildlife: a review. Int J Parasitol Parasites Wildl 4: 178-189. 
Srinivasulu C, Srinivasulu B 2011. South Asian mammals: their diversity, distribution, and status, 1st ed., Springer, New York, 468 pp.

Stokes VL, Spratt DM, Banks PB, Pech RP, Williams R 2007. Occurrence of species of Angiostrongylus (Nematoda) in populations of Rattus rattus and Rattus fuscipes in coastal forests of southeastern Australia. Aust J Zool 55: 177-184.

Tarzhimanova RA, Chertkova AN 1969. Rattostrongylus petrovi (spelt petrowi in text) n. sp., a new nematode from Dryomys nitedula. Trudy Azerb Nauch.-issled Inst Medit Parazit Trop Medit SM Kirova 7: 307-310.

Teixeira CG, de Ávila-Pires FD, Machado RCC, Camillo-Coura L, Lenzi L 1990. Identificação de roedores silvestres como hospedeiros de Angiostrongylus costaricensis no sul do Brasil. Rev Inst Med Trop Sao Paulo 32: 147-150.

Teixeira CG, Thiengo SC, Thome JW, Medeiros AB, Camillo-Coura L, Agostini AA 1993. On the diversity of mollusc intermediate hosts of Angiostrongylus costaricensis Morerea \& Cespedes, 1971 in southern Brazil. Mem Inst Oswaldo Cruz 88: 487-489.

Tenora F, Henttonen H, Haukisalmi V 1983. On helminths of rodents in Finland. Ann Zool Fennici 20: 37-45.

Tesh RB, Ackerman LJ, Dietz WH, Williams JA 1973. Angiostrongylus costaricensis in Panama. Prevalence and pathologic findings in wild rodents infected with the parasite. Am J Trop Med Hyg 22: 348-356.
Travassos L 1927. Nematódeos novos. Bol Biolog Sao Paulo 6: 52-61.

Ubelaker JE, Hall NM 1979. First report of Angiostrongylus costaricensis Morera and Céspedes, 1971 in the United States. $J$ Parasitol 65: 307.

Vargas M, Gómez-Pérez J, Malek E 1992. First record of Angiostrongylus cantonensis (Chen 1935) (Nematoda: Metastrongylidae) in the Dominican Republic. Trop Med Parasitol 43: 253-255.

Vieira FM, Muniz-Pereira LC, Lima SS, Moraes Neto AHA, Guimarães EV, Luque JL 2013. A new metastrongyloidean species (Nematoda) parasitizing pulmonary arteries of Puma (Herpailurus) yagouaroundi (É. Geoffroy, 1803) (Carnivora: Felidae) from Brazil. J Parasitol 99: 327-331.

Weksler M, Percequillo A, Voss R 2006. Ten new genera of Oryzomyine rodents (Cricetidae: Sigmodontinae). Am Mus Novit 3537: 1-29.

Wilson DE, Reeder DM 2005. Mammal species of the world. A taxonomic and geographic reference, 3rd ed., The Johns Hopkins University Press, Baltimore, $2142 \mathrm{pp}$.

Wright JD, Kelly WR, Wadell AH, Hamilton J 1991. Equine neural angiostrongylosis. Aust Vet $J$ 68: 58-60.

Yanchev J, Genov T 1988. Angiostrongylus daskalovi (Nematoda: Filaroididae) from Mustelidae in Bulgaria. Helminthologia 25: 81-88. 